College; Margaret Kams, University of Dayton; Margaret Weir, Brookings Institution; Murray Dry, Middlebury College; Richard Niemi, University of Rochester; Ron Schmidt, California State UniversityLong Beach; Randall Strahan, Emory University; and Sheila Tobias.

For more information on APSA

Research Grant, contact Sheilah Mann at smann@apsanet.org or Jun Yin at jyin@apsanet.org or visit APSA's web site at http//:www.apsanet. org. Details on the 1998 competition will be available on our web page and in the December issue of $P S$.

\section{Goldman Wins Educom Medal}

Jerry Goldman, associate professor of political science at Northwestern University, will receive the 1997 Educom Medal Award for his technological contributions to undergraduate political science teaching, Educom announced in August. Educom cited Goldman's development of the "Oyez" web site as his most important technological contribution to the discipline. The "Oyez" web page (http://oyez.at.nwu.edu/oyez.html) offers online access to audio recordings of hundreds of oral arguments presented before the U.S. Supreme Court together with supporting case summaries. The web site offers ready

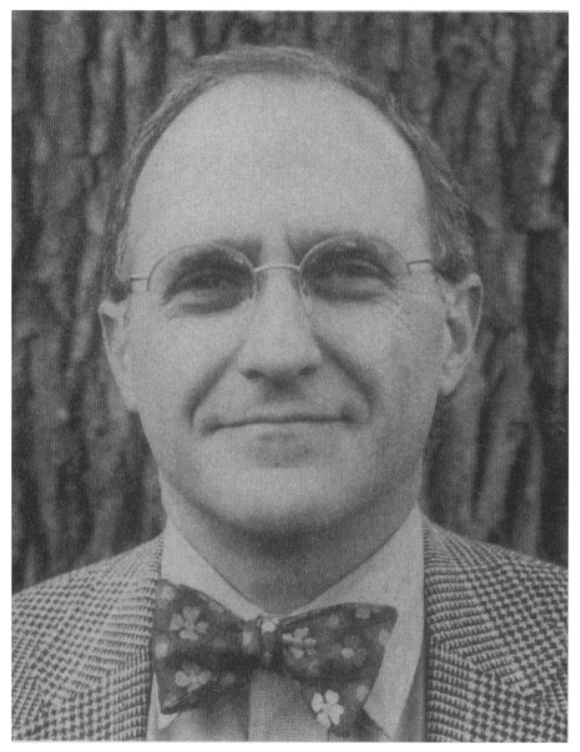

Jerry Goldman access to materials previously unavailable to the entire research and teaching community.

For the third consecutive year, Educom, a nonprofit consortium of higher education institutions, invited a group of professional disciplinary societies to honor individuals who contribute to undergraduate education through information technology. This year, APSA joined the American Philosophical Association, the American Society of Mechanical Engineers, and the Geological Society of America as partner societies in the 1997 Educom Medal Awards Program. Partner societies were asked to select their nominees based on the following criteria: a significant pedagogical problem fundamental to the discipline; an innovative solution offering clear advantages over other techniques; and a substantial impact on improved student learning.

APSA's selection committee was comprised of Kent Portney of Tufts University, Cecilia Manrique of the University of Wisconsin-La Crosse, and George Watson of Arizona State University.

Award winners will be honored at the Educom annual conference to be held in Minneapolis, October 28-31.

\section{$1^{\text {th }}$ Annual Ralph Bunche Summer Institute}

\section{"Opening New Doors into the World of Political Science"}

The 1997 Ralph Bunche Summer Institute, hosted by the University of Virginia for the second consecutive year, attracted 15 energetic and talented African American undergraduate students. The Institute, organized and orchestrated through a collective effort by the Ralph Bunche Summer Institute staff on the host campus and the American Political Science Association, is designed to introduce African American students to the world of graduate study and encourage application to Ph.D. programs in political science. Louisiana State University, Southern University, Spelman College, Morehouse College, Georgia State University, Emory University and Clark Atlanta University have also hosted Institutes over the last eleven years.

The 1997 Institute was held on the campus of the University of Virginia under the leadership of Professor Steven E. Finkel, who directed the Institute last year as well. In addition to directing and organizing the program, Dr. Finkel, Professor in the Government and Foreign Affairs Department at the University, taught the quantitative course of the program, "Political Analysis." Professor Paula McClain, former Chair of UVA's Department of Government and Foreign Affairs, taught the second course, "Race and American Politics." Dr. McClain has been instrumental in fundraising for the Institute. In addition to the two classes, the students attended lectures by distinguished scholars in the field of political science, and participated in a series of discussions on ethics in political science and the profession.

Through this rigorous program, the Institute's objective-to encourage the fellows to pursue graduate studies in political science - has had great success. 1997 Ralph Bunche Fellow Reggie McGahee from South Carolina State University, commented that "the Ralph Bunche Summer Institute has opened new doors for me into the world of political science." Reggie remarked that his experience as a fellow was "demanding, enriching, and thoughtprovoking" and that he hopes to draw upon this experience thoughcontinued graduate work. In a similar manner, Bunche Follow Khalilah Brown from the University of Virginia stated: "having the opportunity to interact with other students from across the country, establish a working rapport with the professors, and meet prominent scholars in the discipline, has helped me to better define my academic interests and abilities."

Students who have participated in the program over the past decade have reported improvement in their analytical, writing, and quantitative skills. Many students go on to graduate school, often with full graduate fellowships and teaching assistantships. A number of Institute participants have received their Master and Ph.D. degrees, and three have al- 